Paper-Creative Merging and Practical Application of "History of Modern Design" Course Online Teaching Platform Construction and Flipped Classroom Teaching Mode

\title{
Creative Merging and Practical Application of "History of Modern Design" Course Online Teaching Platform Construction and Flipped Classroom Teaching Mode
}

\author{
https://doi.org/10.3991/ijet.v12i02.6318 \\ Zhu Tiejun \\ Anhui Polytechnic University, Wuhu, China \\ ztj@ahpu.edu.cn
}

\begin{abstract}
Design major students of Chinese universities and colleges exists a common learning concept on emphasizing the practice but contempt of theory. Students' interest in learning theoretical courses, especially design history courses is more diluted. In order to explorative change such phenomenon, researchers conducted a "History of Modern Design" course teaching of Sinoforeign cooperative education program as a pilot reform, drawing the current international hot network teaching resources and methods, innovatively constructing multivariate course online teaching platform, and combined with the flipped classroom teaching model which was vigorously advocated by the Chinese educational department. Empirical research and practice results show virtual course and online teaching and learning space. Application of flipped classroom teaching mode changed boring theory taught into exciting interactive teaching and learning. It not only trained independence of students' thinking, learning autonomy and the ability to explore knowledge, it also highly pushed students to innovatively apply design history theory. The course innovative reform achieved significant results. It was proved that can widely spread and apply in design history courses teaching of art and design majors of Chinese universities and colleges in the future.
\end{abstract}

Keywords-Flipped Classroom, Online Teaching Platform, History of Modern Design Course, Integration and Innovation, Practical Application

\section{Introduction}

Online teaching platform created network virtual environment relying on radio and television network, computer Internet and mobile wireless network resource in which to carry out all teaching modules and functions of teaching and learning systems. "Initial idea of flipped classroom was from teaching practice of two chemistry teachers whose name is Jonathan Bergman and Aaron Sams respectively. They are teachers of Woodland Park School of the United States." [1] Flipped classroom is called in- 
Paper-Creative Merging and Practical Application of "History of Modern Design" Course Online Teaching Platform Construction and Flipped Classroom Teaching Mode

verted classroom as well, it has become the focus of attention of global education since its origin in 2007. The most significant feature of flipped classroom not only reverses the teachers and learners' roles in the teaching process and innovates organizational forms and linear process of teaching activities, meanwhile, "an inverted (or flipped) classroom is a specific type of blended learning design that uses technology to move lectures outside the classroom and uses learning activities to move practice with concepts inside the classroom." [2] The innovative teaching concept and hybrid teaching mode of flipped classroom is mainly due to construction of online teaching space. Provided or recommended online learning resource by teachers and pluralistic online teaching methods built flexible, efficient, cooperative and interactive online teaching platform. It gave a solid guarantee for the flipped classroom to realize the real "Invert" and the significantly improved teaching quality.

"History of Modern Design" is a professional basic compulsory course in art and design major curriculum system of Chinese universities and colleges. It is an important part of the theoretical teaching. However, from the point of view of the actual teaching effect, it existed a common learning concept on emphasizing the practice but contempt of theory in art and design major students. Students' interest in learning art and design theoretical courses is more diluted, or even "in today's art and design education field, many people think that art and design theoretical education seems dispensable in terms of the entire art and design education."[3] Furthermore, current Chinese design theory course teaching: "The teaching method is single, the teaching update is not enough"[4]Therefore, the researchers elected "History of Modern Design" course of a Sino-foreign cooperative undergraduate major (In 2014, Anhui Polytechnic University (AHPU) held the Visual Communication Design Undergraduate Education program (VCDUE program) with University of Bridgeport (UB) of the United States.) as a teaching reform experimental item and fully relied on Sino-foreign cooperative educational resources and advantages to systematically run the application of flipped classroom teaching mode which was based on online teaching platform. The reform aims to focus on promoting quality-oriented education and effectively improving the teaching quality of teaching and mainly changing traditional teaching mode. It is hoped to rely on flipped classroom and online teaching platform to strenuously overcome the long-standing study habit that students are always dependent upon teachers' teaching to learn. It strives to train students' independent thinking and learning autonomy, become boring theory teaching to interactive teaching and flipped teaching. It is also hoped to improve the online learning ability of students, stimulate students' learning enthusiasm, enhance learning efficiency, fully exert students' personalities and specialties, and promote personalized study through actively creating a digitized online teaching platform and teaching environment.

\section{Current Course Teaching Situation and Available Course Resources}

As a Sino-foreign cooperative education program, the two sides conducted in-depth and detailed negotiations and closely cohesion. Visual Communication Design major 
Paper-Creative Merging and Practical Application of "History of Modern Design" Course Online Teaching Platform Construction and Flipped Classroom Teaching Mode

of AHPU matches the Graphic Design major of UB. In United State, design theory research is especially developed. In design major curriculum system of high education in the US, design theory part has a large proportion. In terms of US graphic design major, design history courses accounted for $20 \%-30 \%$ of professional compulsory courses.[5]Thus, in education and teaching plan of VCDUE program, "History of Modern Design" is a professional basic compulsory course which is designated by UB. It is open in the second semester, a total of 3 credits and 48 teaching hours. In addition, VCDUE program also sets up many theoretical courses such as "Survey of Art History I", "Survey of Art History II", "History of Graphic Design" and forms a systematic design theoretical courses system. (TABLE 1). In terms of the aim of setting up this course, wide learning design history courses including the "History of Modern Design", it can not only help students to historical and cultural criticize and analyze the design phenomena, but can also carry out a historical review of design practice, utilize theory to guide practice, and effectively enhance students' thinking ability and design innovation.

Table 1. Ahpu-Ub Visual Communication Design Undergraduate Education Program Curriculum

\begin{tabular}{|c|c|c|c|}
\hline \multicolumn{4}{|c|}{ (1) } \\
\hline $\begin{array}{l}\text { FIRST SEMESTER } \\
3 \text { ADSN } 103 \text { 2-D Design Principles } \\
3 \text { ADSN } 105 \text { Drawing I } \\
3 \text { ADSN } 119 \text { Intro to Computer Apps I } \\
3 \text { ADSN } 117 \text { Survey of Art History I } \\
3 \text { FYS C101 First Year Seminar } \\
15 \\
\text { SECOND SEMESTER } \\
3 \text { ADSN } 108 \text { 3-D Design Principles } \\
3 \text { ADSN } 106 \text { Drawing II } \\
\text { 3 ADSN } 219 \text { Intro to Computer Apps II } \\
3 \text { ADSN } 377 \text { History of Modern Design } \\
3 \text { ENG } 101 \text { Composition \& Rhetoric Core } \\
\text { 15 } \\
\text { THIRD SEMESTER } \\
3 \text { GDSN } 255 \text { Graphic Design Studio I } \\
\text { (Print) } \\
\text { 3 ADSN } 209 \text { Painting I } \\
3 \text { ADSN } 118 \text { Survey of Art History II } \\
3 \text { GDSN } 204 \text { Calligraphy \& Letterforms } \\
3 \text { Soc Sci Social Science Core } \\
3 \text { Hum Humanities Core } \\
18\end{array}$ & $\begin{array}{l}\text { FOURTH SEMESTER } \\
3 \text { GDSN 256 Graphic Design } \\
\text { Studio II (Print) } \\
\text { 3 GDSN 203 Typography } \\
\text { 3 ADSN } 231 \text { Photography } \\
\text { 3 ADSN } 379 \text { History of Graphic } \\
\text { Design } \\
\text { 3 ADSN } 207 \text { Illustration Studio I } \\
\text { 3 Soc Sci Social Science Core } \\
18 \\
\text { FIFTH SEMESTER } \\
3 \text { GDSN } 305 \text { Graphic Design } \\
\text { Studio III (Packaging) } \\
\text { 3 ADSN 233 Motion Graphics } \\
\text { 3 ADSN 225A Web Applications I } \\
3 \text { Nat Sci Natural Science Core } \\
\text { 3 MCOM Elective } \\
\text { 15 } \\
\text { SIXTH SEMESTER } \\
\text { 3 GDSN 306 Graphic Design } \\
\text { Studio IV (Web) } \\
\text { 3 GDSN 225B Web Applications II } \\
\text { 3 GDSN 212 Visual Semiotics } \\
\text { 3 Hum Humanities Core } \\
\text { 3 Nat Sci Natural Science Core } \\
\text { 15 }\end{array}$ & $\begin{array}{l}\text { SEVENTH SEMESTER } \\
3 \text { GDSN } 355 \text { Graphic Design } \\
\text { Studio V (Publishing) } \\
3 \text { ADSN/GDSN elective } \\
\text { 3 GDSN 425A Design Service } \\
3 \text { Liberal Arts Elective } \\
3 \text { Caps C390 Capstone Seminar } \\
\text { Core } \\
15 \\
\text { EIGHTH SEMESTER } \\
3 \text { GDSN } 356 \text { Graphic Design } \\
\text { Studio VI (Thesis) } \\
3 \text { ADSN } 304 x \text { Business Practices } \\
3 \text { MCom } 339 \text { PR \& Advertising } \\
\text { Campaigns } \\
3 \text { GDSN 425B Design Service } \\
\text { 15 GDSN } 398 \text { Internship } \\
\text { Total Semester Hours } 126 \\
\text { *Not include common } \\
\text { compulsory courses such as } \\
\text { Moral Cultivation and Basic Law } \\
\text { Education, PE. Basic English. } \\
\text { Current situation and Policy, } \\
\text { College Mathematics and so on. }\end{array}$ & $\begin{array}{l}\text { DESIGN ELECTIVES } \\
\text { Painting I } \\
\text { Painting II } \\
\text { Illustration Studio I } \\
\text { Illustration Studio II } \\
\text { Video I } \\
\text { Motion Graphics } \\
\text { Soundtrack } \\
\text { Maya A (B,C,D)(3-12cr) } \\
\text { Calligraphy \& Letterforms } \\
\text { Typography II Type Design } \\
\text { Typography III ID \& Logo } \\
\text { Design Service (A, B, C) } \\
\text { Independent Study } \\
\text { Internship A,B (2-6cr) }\end{array}$ \\
\hline
\end{tabular}

"History of Modern Design" course uses the originality, enlightenment, development and maturity of modern design as timeline to comprehensive and systematic elaborate various art design trend and their performance characteristics, representative figures and works. With an emphasis on different countries, different styles, different backgrounds of the formation and development of modern design art system, this course teaching in-depth analyzes kinds of examples, phenomena and carries out design practice at the same time, to promote students in the full-depth grasp and understanding of all kinds of contemporary art and design thoughts, and to help students to 
Paper-Creative Merging and Practical Application of "History of Modern Design" Course Online Teaching Platform Construction and Flipped Classroom Teaching Mode

combine with what they have learned to implement application in Chinese contemporary art and design research and practice.

Since VCDUE program was established in September 2014, although the course teacher uses bilingual teaching as well as many new teaching methods, because of the limitation to the lack of teaching facilities, a large number of students as well as more traditional teaching environment and other factors, teacher's teaching potential could not get the depth of excavation and give full exertion, students' learning motivation and interest also failed to be effectively stimulated. Therefore, the practical effect of teaching was not good, current teaching resources was not yet available meet and adapt to flipped classroom teaching mode and teaching reform. (TABLE II)

Table 2. A List Of Teaching Resources Of "History Of Modern Design" Course Of Vcdue Program In March 2015(The First Time It Has Set Up)

\begin{tabular}{|l|c|l|c|l|l|}
\hline \multicolumn{1}{|c|}{ Item } & No. & \multicolumn{1}{c|}{ Item } & No. & \multicolumn{1}{c|}{ Item } & No. \\
\hline Teacher & 1 & Teaching Courseware & 10 & $\begin{array}{l}\text { Research Papers and Teaching Achieve- } \\
\text { ments }\end{array}$ & 7 \\
\hline Students & 39 & Exercises and Tests & $97+2$ & Examination Item Database & 2 \\
\hline Multimedia Facilities & 1 & Online Teaching Resource & 0 & Teaching Video & 12 \\
\hline $\begin{array}{l}\text { Practical Teaching } \\
\text { Places }\end{array}$ & 3 & Courses dedicated computer & 1 & $\begin{array}{l}\text { Courses Dedicated Classroom (Traditional } \\
\text { Setup) }\end{array}$ & 1 \\
\hline
\end{tabular}

\section{Construction of Online Teaching Platform}

In view of no any form online teaching resources and platforms in current course teaching system, researchers orient to build systematical online teaching platform as a breakthrough of this course reform. The online teaching platform "contains all the necessary teaching materials." [6]On the other hand, new flipped classroom design and application must rely on well-functioning and powerful online teaching platform as well. Thus, researchers fully take advantages of the current international education relatively new and relatively mature online educational resources and learning interface and specifically apply to the second time "History of Modern Design" course teaching (There are 35 in this cohort of students.) in the second semester of 20152016 academic year (March 2016). It provides a solid foundation and effective protection to the practical application of flipped classroom.

\subsection{Hardware facilities construction}

Whether it is the effective implementation of flipped classroom or the construction of online teaching platform, it requires specialized hardware equipments and infrastructure. For this reason, teaching management staff and course teacher fully investigated some universities and colleges' flipped classroom construction programs and useful experience in United Kingdom, Singapore and Taiwan. On the basis of these investigations, on the one hand, the researchers selected the appropriate classroom to carry out reconstruction. In addition to the existing multimedia devices, the research- 
Paper-Creative Merging and Practical Application of "History of Modern Design" Course Online Teaching Platform Construction and Flipped Classroom Teaching Mode

ers added many new types of equipment such as LCD screen, wireless networks, embedded whiteboard, audio video equipments, etc.(Figure 1) On the other hand, the researchers especially set a specialized counseling room (Students learning teams can use this place to discuss and complete team tasks as well). In addition, in order to create a better information technology courses teaching environment, the researchers also allocated a network computer room and multi-media classrooms to diversified and widely construct, implement and apply online teaching platform.

\subsection{The online questionnaire regularly published}

Survey feedback mechanism itself is a course teaching module and online learning and communication way. The researchers depended on well-known international online survey platform "surveymonkey (https://www.surveymonkey.com)", through online questionnaires regularly published (Figure 2), to encourage students to know and use the same time, but also to strengthen the online communication frequencies between teachers and students. The feedback data was conducive to the dynamic adjustment for course teaching as well.

Pre-class flipped classroom teaching mode application investigation and learning tasks discussion between teachers and students: To enable students to better understand and adapt to the flipped classroom teaching mode, the researchers designed an investigation questionnaire for students and to ask students to participant in advance. The questionnaire had been basically introduced flipped classroom and online teaching platform at the same time, on the one hand, it aimed to preliminary assess students' perceptions and interests of the new teaching mode. On the other hand, on the basis of acquiring and knowing students learning ability and learning status, the researchers hoped to fully listen and understanding students' thinking, attitude and opinion according to questionnaire feedback, and discussed the course

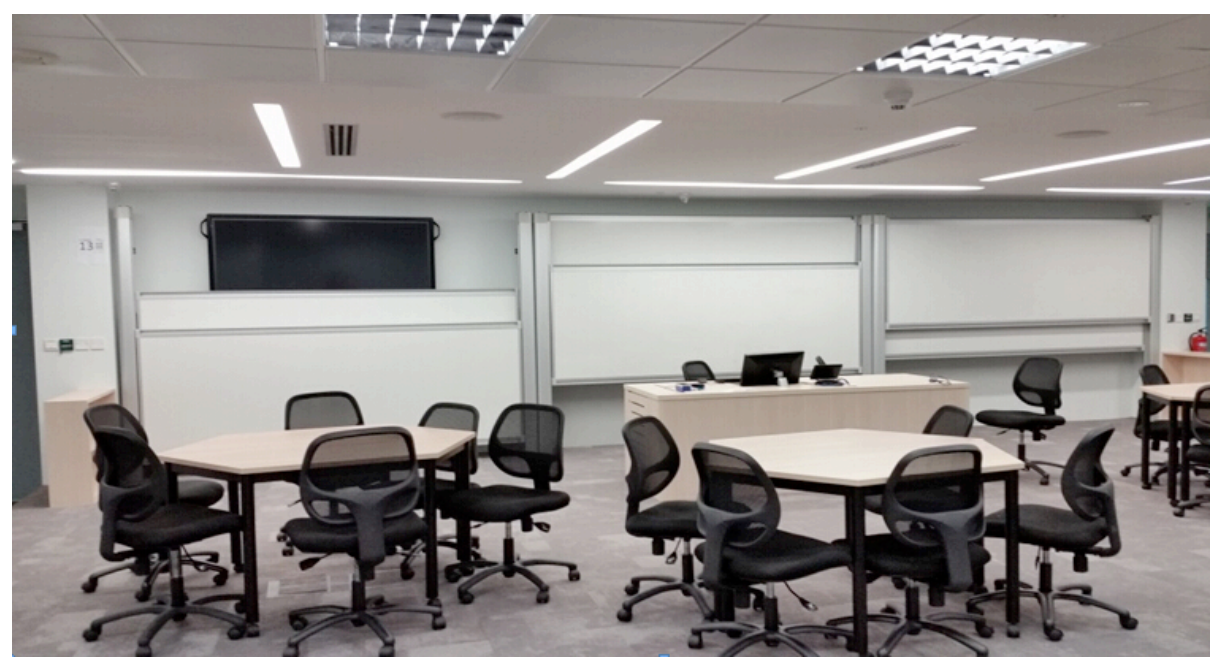

Fig. 1. One corner of flipped classroom after reconstruction 
Paper-Creative Merging and Practical Application of "History of Modern Design" Course Online Teaching Platform Construction and Flipped Classroom Teaching Mode

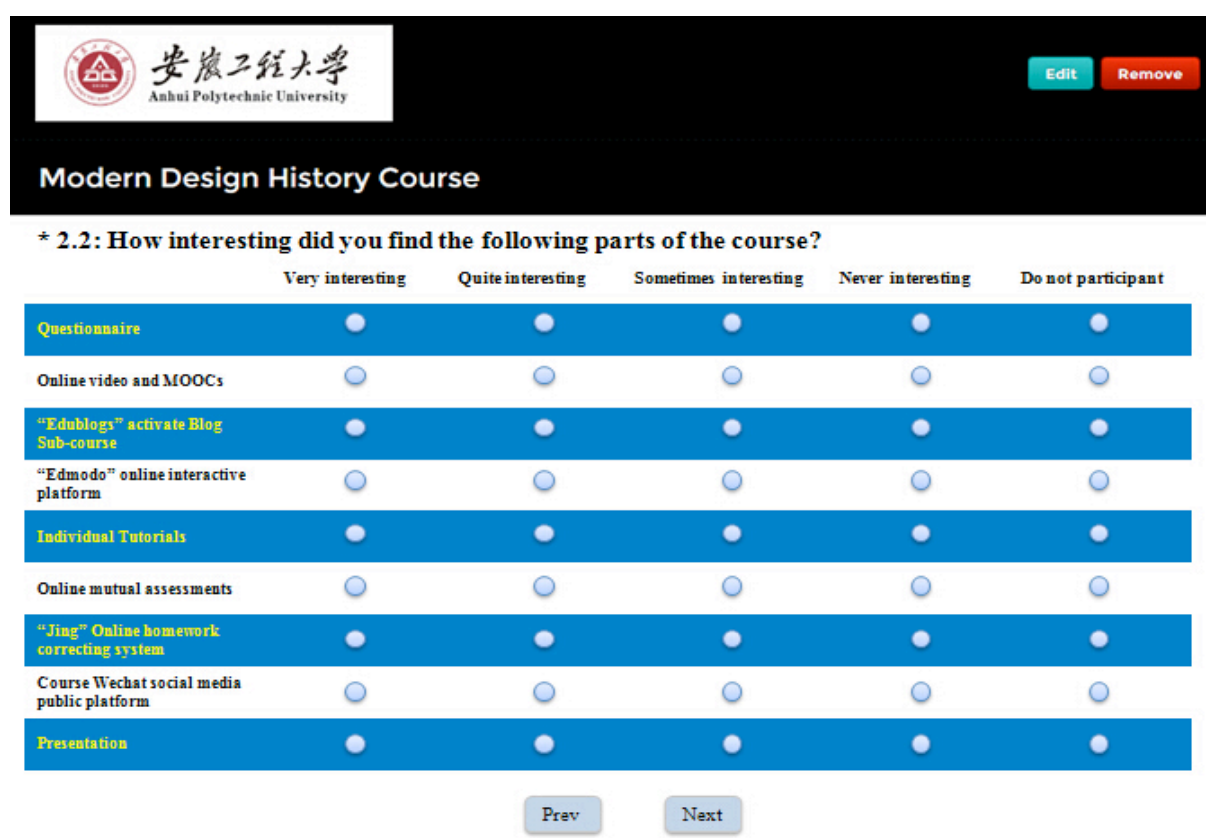

Fig. 2. For students course online questionnaire interface

curriculum with students and made staged teaching task list together. Namely through investigation questionnaire to introduce and highlight the course core knowledge, teaching key points and difficult points, the researchers collected students views and suggestions, so as to better meet the coming teaching requests and effectively correspond and fit flipped classroom implementation processes.

Questionnaire involved three parts and a total of 45 questions. The first part was students' basic information inquiries and included 5 questions. The second part mentioned the concept of flipped classroom, application target, implementation form and particular mode and had 20 questions. Item 1 to 3 asked students whether they had ever known or experienced flipped classroom; 4 to 9 investigated students' attitudes and ideas about "History of modern design" course using the flipped classroom teaching mode; 10 to 15 specialized inquired respondents that they hope to construct and apply which form online teaching resources and platform; 16 to20 invited students to pre-judge the possible occurred problems during the whole course learning process and explain the reason. The third part firstly presented the teaching objectives and learning tasks of "History of modern design" course and also put forward 20 questions. Item 1 to 4 were survey of students' awareness of course; 5 to 10 investigated students' understanding and recognition extent about teacher setting the learning tasks; 11 to 16 invited students to present their ideas and recommendations about what knowledge they want to learn comparing teacher's requirements and why they hope to adjust; 17 to 20 asked what the students expect to learn from this course and let them to put forward their interest points associated with this course content based on individual situation. 
Paper-Creative Merging and Practical Application of "History of Modern Design" Course Online Teaching Platform Construction and Flipped Classroom Teaching Mode

Mid-course course questionnaire investigation of collecting data for future counseling and evaluating students' learning and experience effect: In the middle stage of the course teaching, the researchers used online questionnaire again to assess the flipped classroom learning experience effects of students and collected feedback information to facilitate the conduct of individual counseling and tutorial. The questionnaire had a total of 33 questions: Item 1 to 6 investigated students learning experience and harvest in the first half period of course teaching; 7 to 12 referred to students' encountered practical problems and the reasons analysis in their current learning stage; 13 to 19 related to students evaluation of currently using online teaching and learning resources; 20 to 27 inquired students what aspects and ways expected to receive help and guidance; 28 to 33 investigated students' learning interests of second-half course teaching stage and their individual learning content and learning way on which they like to focus.

Teaching evaluation questionnaire: After the completion of the course teaching, the researchers invited students to do the teaching process evaluation according to their whole learning experience. The questionnaire mainly involved seven aspects, each aspect had five questions, a total of 35 questions, namely: the first aspect evaluated the effectiveness of flipped classroom teaching mode; the second aspect evaluated the operation application of online teaching platform; the third aspect evaluated the applicability of online learning resources; the fourth aspect evaluated teacher's controlling capability to flipped classroom; the fifth aspect evaluated the function and effect of teacher tracking tutorial, group communication, students online mutual assessment and other sectors during the whole teaching process; the sixth aspect let students to point out what facets need to improve for this flipped classroom teaching mode and course online teaching platform; the seventh aspect was self-evaluation and evaluated students self-expression situation and what benefits they had achieved during course learning process.

Network Examination System: exam module design function of "Surveymonkey" can be easily set single choice exercise, multiple choice exercise, fill-in-the-blanks exercise, $\mathrm{T} / \mathrm{F}$ exercise, essay-type question and even drawing graphics exercise, therefore, so as to change the traditional offline examination way, the course teacher utilized this resource to carry out an online test in classroom near the end of this course.

But during actual implements, it is noticed that making use of Surveymonkey software for online examination can cover objective type of exam but not all subjective. So as to effectively solute this issue and provide better experience and application effect for next cohort of students, the researcher propose an improved and alternative solution, it is also an online examination system called TomExam (http://www.tomexam.com/).

TomExam is based on JAVA and MYSQL development of a free and specialized network examination system. It can be stable and smooth running on Windows and Linux platform. The course teacher can quickly and easily create test question database, publish papers and organize the online examination. TomExam supports a variety of common subjective and objective questions. More importantly, questions can not only be batch import, but also can provide random paper form. In another word, it can 
Paper-Creative Merging and Practical Application of "History of Modern Design" Course Online Teaching Platform Construction and Flipped Classroom Teaching Mode

realize random mixed arrangement of test questions. Therefore, this kind of online examination can effectively and easily prevent cheating.

\subsection{Courses online interactive platform}

The course reform researchers and teacher exploratively apply a new teaching method in classroom teaching. Namely, on the one hand, they retained face to face traditional teaching form, on the other hand based on constructing courses online interactive platform, the researchers tried them best to realize other on-site teaching modules, such as Q \& A activity, courseware display, discussion and communication, students' mutual evaluation to wholly network transplant and online operation. This way formed the offline classroom innovative combination of virtual classroom, not only inherited the lively form of classroom teaching, but also grafted into the latest online education technology. Specific implementation process was: First, according to each lesson's teaching knowledge point, Teachers introduced each lesson teaching tasks, teaching courseware, multiple audio and video media information or related websites, thinking questions to the course online interactive system. During on-site teaching process, teacher only pointed out classroom learning tasks and extracted the core knowledge of each lesson to teach. Next, the students would log in course online interactive platform to independent learning and complete the assigned tasks, and teacher was responsible for individual helping students to solve specific issues during the whole process.

Because teacher provided a variety of learning resources, students could freely choose the learning resource according to their interests and preferences points. Therefore, each student's learning content and the task completed situation was not the same. And for each student's learning completed situation, not only teacher but also other students are able to see on the platform. Based on this characteristic, the teacher asked each student must select 5 students' learning tasks to give comments after completing their own learning tasks. This approach could not only make students conduct real-time communication and discussion together, but also enabled them to find other students' unique insights and ideas of analyzing and solve problems and promote them to learn with each other. Meanwhile, because the platform could save all the records of teacher' teaching and students' learning, students were very easy to review and track learning knowledge. On the other hand, students could also realized resources sharing by means of other students' learning thought, learning discovery and recommended description so as to maximize learning efficiency during limited time.

Course online interactive platform relied on a global educational contents sharing platform and electronic network teaching platform-"Edmodo" (https://www.edmodo.com) to realize. (Figure 3). Teacher must first create an online class group at this platform and guided all students to join. Classroom need to use network computer room. Because of a total of 35 class students, teacher divided students into two groups. Each teaching was three hours to effectively ensure teacher's individual tutoring time and teaching quality and effect, so as to achieve new height of exploration, speculation, interaction and practice of the depth of course teaching. 
Paper-Creative Merging and Practical Application of "History of Modern Design" Course Online Teaching Platform Construction and Flipped Classroom Teaching Mode

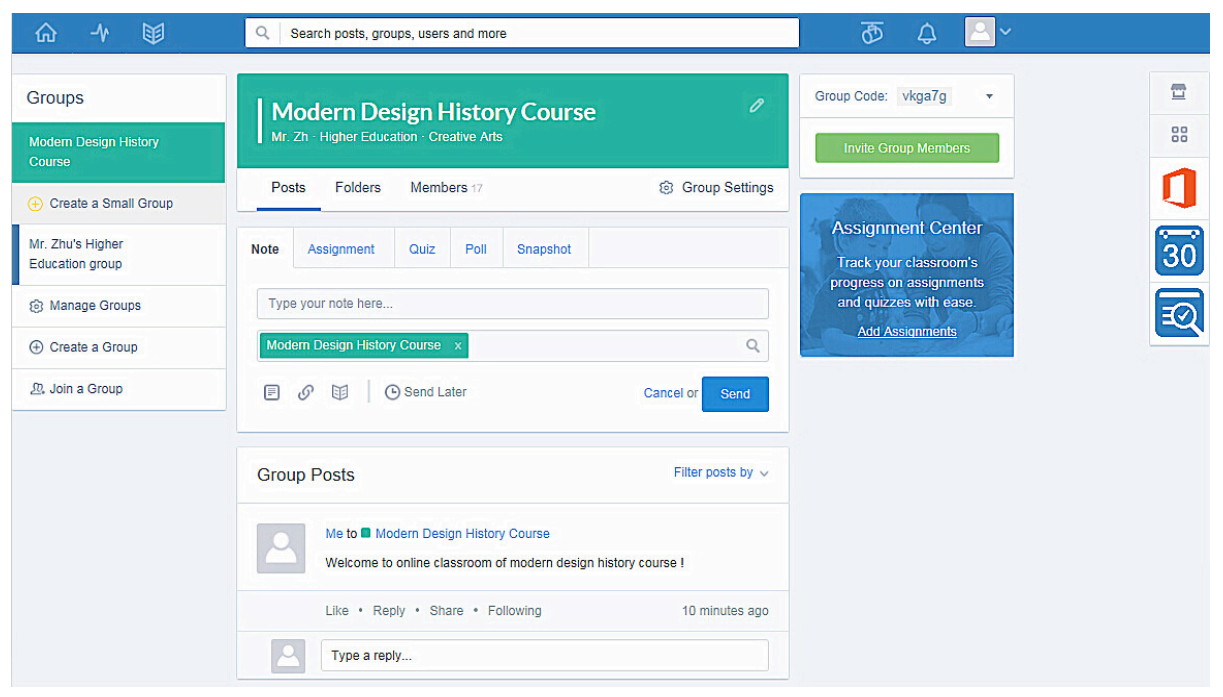

Fig. 3. "History of Modern Design" course "Edmodo" online interactive platform interface

\subsection{Online homework correcting system}

Jing ${ }^{\circledR}$ (https://www.techsmith.com/jing.html) is internationally popular fast screen recording software. The researchers used its feature and function to create an online homework correcting system and video sharing platform, which was unique that it not only enabled students to online submit their homework and teacher online revise and feedback homework as well, put offline homework correcting module implant network platform, but teacher could also modify homework by the ways of audio and video instead of traditional paper marking. Because the voice messaging amount was far greater than the few written comments, the teacher could both be highlighted the wrong part and extend knowledge connotation through audio and video form, and even directly gave some examples to explain, at the same time, such interpretation could be subtle and clear and smooth so that realized in-depth, comprehensive comments and effectively avoided the common shorts of traditional correcting way such as low massage amount, inadequate comments due to limited space caused students could not effectively understand teacher's deep meaning and grasp the key knowledge points. Furthermore, through this online platform, students could be fully know the whole process of teacher homework correcting, and found teacher's problem-solving thinking angles, methods and paths or design ideas, but also this correcting form was more accessibility, like teacher conducting face to face tutorial and communication, rather than just facing a few lifeless cold comments.

The innovative application of Jing online homework correcting system (Figure 4) gave rise to great repercussions in course teaching. All the students were given good feedback opinion after they had experienced the new homework correcting way. Jing not only brought novel experience to students, but also greatly stimulated their learn- 
Paper-Creative Merging and Practical Application of "History of Modern Design" Course Online Teaching Platform Construction and Flipped Classroom Teaching Mode

ing interests. Students liked and even always looked forward to getting teacher's electronic comments. Viewing teacher's reviews became a joy and had been accompanying with whole course learning process. "Online homework submission and correction was most attractive by students"[7]Besides the practice of the Jing online platform, depend on the TOEFL or IELTS exam requirements because these students will study abroad in the last two academic years, teacher vigorously promoted students to regularly write English paper and recommended them to use online paper correcting system such as "JuKuu"(http://www.pigai.org/) or "1checker" (http://www.1checker.com) and other free online paper correcting resources to do the self-checking, modification and improvement.

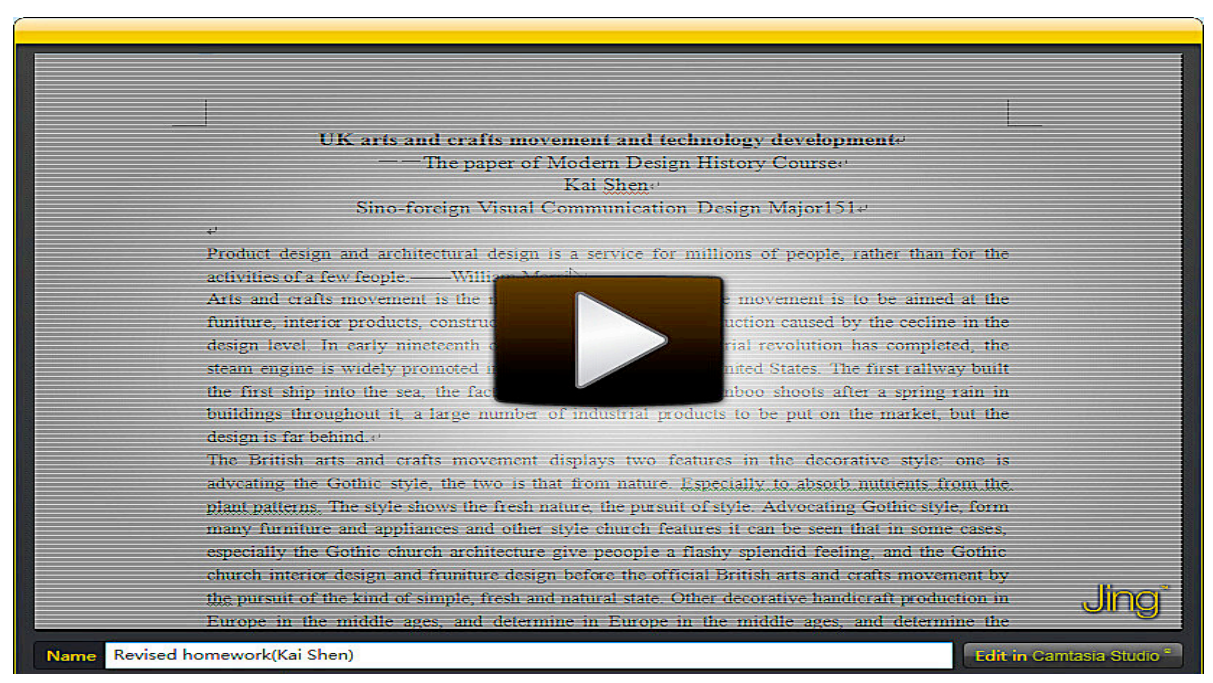

Fig. 4. Jing Online homework correcting system interface

\subsection{MOOC electronic distance teaching platform application}

MOOC as the current widely used and very convenient online distance teaching platform, its many advantages such as plenty of English MOOCs, diverse and global learning channels without the constraints of time and space, reaching real foreign learning environment, innovative teaching modules and effective expansion of global visual field very met the talents cultivation requirements of Sino-foreign cooperative education major. More importantly, as a design history course which student had generally considered very boring, the construction of the MOOC platform constantly provided a steady, fresh and high quality teaching and learning resources for "History of Modern Design". These related MOOCs brought not only the excellent teachers' rich experiences, profound knowledge system and special teaching methods, but also included multi-directional course displays which combined design history and design frontier. MOOC distance teaching platform application had contributed to significant- 
Paper-Creative Merging and Practical Application of "History of Modern Design" Course Online Teaching Platform Construction and Flipped Classroom Teaching Mode

ly increase students' learning interest degree, autonomous learning motive force and creative thinking ability.

In this regard, according to the nature and knowledge range of "History of Modern Design" course of VCDUE program, based on fully investigating and knowing students' familiarity degree of the MOOCs, the researchers one hand specifically opened an online MOOCs introduction platform and teaching resource information database for students which added many introductory materials and multimedia lectures about various of MOOCs teaching platform and how to select, start and complete MOOCs. On the other hand, the researchers invited 6 excellent professional teachers to elaborately select 24 excellent courses, which had strong association with "History of modern design" course but focused on broader range of this course, from massive domestic and international MOOCs resources. These courses were divided into four categories, each category of had six courses (TABLE III). Students could choose these recommended courses to learn or tracked the clue to participant in other relevant MOOCs.

\subsection{Online video resources}

For the flipped classroom teaching mode, the teaching video resources are the key factor as well as the premise of realizing "students learning before teaching". "To really achieve the flipped classroom, it is recommended to re-orient the role of teachers and students and high-quality make course teaching video"[8]Therefore, according to course important knowledge points, the researchers not only selected 12 excellent teaching short videos from the television network resource and online resource such as video-on-demand platform, Ted, YouTube and MOOCs, but also relied on teacher's rich teaching experience, the ability of grasping and understanding course knowledge structure and interviewed other learners to make 12 videos. The main types of these teaching videos included learning experiences introduction type, the type of deep interview of teachers, interesting create and design type, situational simulation type, etc. In order to fully guarantee the attention of learners, selected video length was generally not more than 15 minutes. More importantly, these videos closely linked to each other but isolated. They established an orderly, coordinated and connected video teaching chain. Furthermore, to safeguard the teaching video resources to download and learn whenever and wherever possible, course teacher respectively opened learning space on international universal Bb((Mobile Learn) platform and Chinese prevalent online storage platform- "Baidu Cloud Disk" and also registered a class group and intelligent cloud database on Chinese mainstream social media "QQ" to upload all the teaching videos. The formation of a special online cloud service learning platform, students could easily download teaching videos in computer, laptop or scan two-dimensional code to download by mobile devices without time and space limit, and then carried out autonomous learning and thought questions according to teaching video contents. Next, students brought these questions to the classroom to consult teacher or panel discussion. In this sense, flipped classroom had already come true. 
Paper-Creative Merging and Practical Application of "History of Modern Design" Course Online Teaching Platform Construction and Flipped Classroom Teaching Mode

Table 3. The Selected Relevant Moocs Resources For Students

\begin{tabular}{|c|c|c|c|}
\hline $\begin{array}{l}\text { Course } \\
\text { Type }\end{array}$ & $\begin{array}{c}\text { Num } \\
\text { ber }\end{array}$ & Course Name & Course Source and Teaching Languag \\
\hline \multirow{6}{*}{$\begin{array}{c}\text { History } \\
\text { design } \\
\text { style topic } \\
\text { Type }\end{array}$} & \multirow{6}{*}{6} & Arts, Crafts, and Machines & EdX (English) \\
\hline & & Art Nouveau in Europe & $\begin{array}{l}\text { China online open resources platform } \\
\text { (Chinese) }\end{array}$ \\
\hline & & Scandinavia and Modern Design & China open courses platform(Chinese) \\
\hline & & $\begin{array}{l}\text { The Bauhaus reassessed: sources and design } \\
\text { heory }\end{array}$ & Coursera（English） \\
\hline & & $\begin{array}{l}\text { The new typography: A handbook for Moder } \\
\text { esigners }\end{array}$ & $\begin{array}{l}\text { Icourse and CCTV open courses } \\
\text { (Chinese) }\end{array}$ \\
\hline & & Politics, Pluralism, and Postmodernism & Ted（English） \\
\hline \multirow{6}{*}{$\begin{array}{l}\text { History } \\
\text { design } \\
\text { phenome- } \\
\text { non analy- } \\
\text { sis type }\end{array}$} & \multirow{6}{*}{6} & $\begin{array}{l}\text { Fashion Style Icons and Designing from } \\
\text { istorical Elements }\end{array}$ & Sina open courses (Chinese) \\
\hline & & Ideas from the History of Graphic Design & Online lecture (Chinese) \\
\hline & & A life of design & Ted（English） \\
\hline & & Modernism: Design, Utopia, and Technology & National Excellent courses (Chinese) \\
\hline & & $\begin{array}{l}\text { Design and Mass Appeal: A Culture of Con- } \\
\text { amption }\end{array}$ & Sohu online education (Chinese) \\
\hline & & Anti-design in Italy & EdX (English) \\
\hline \multirow{6}{*}{$\begin{array}{c}\text { History } \\
\text { deign } \\
\text { master } \\
\text { Biography } \\
\text { Type }\end{array}$} & \multirow{6}{*}{6} & $\begin{array}{l}\text { Immortal Art: Walking into the Masters and } \\
\text { te Classics }\end{array}$ & Sina open courses (Chinese) \\
\hline & & Andy Warhol & Udacity（English） \\
\hline & & $\begin{array}{l}\text { Western Modern Design: Masters and Clas- } \\
\text { cs }\end{array}$ & Online lecture (Chinese) \\
\hline & & Pioneers of modern design & National Excellent courses (Chinese) \\
\hline & & The Influence of William Morris in Britain & Udacity（English） \\
\hline & & $\begin{array}{l}\text { The Lesser Design: Ludwig Mies Van der } \\
\text { ohe }\end{array}$ & Coursera（English） \\
\hline \multirow{6}{*}{$\begin{array}{l}\text { Design } \\
\text { history } \\
\text { theory } \\
\text { practice } \\
\text { type }\end{array}$} & \multirow{6}{*}{6} & Design: Creation of Artifacts in Society & $\begin{array}{l}\text { China online open resources platform } \\
\text { (Chinese) }\end{array}$ \\
\hline & & $\begin{array}{l}\text { Practice Based Research in the Arts and } \\
\text { esign }\end{array}$ & Sohu online education (Chinese) \\
\hline & & Demand, Supply and Design Power & NetEase open courses (Chinese) \\
\hline & & $\begin{array}{l}\text { Visual Identity, Information, and Art Direc- } \\
\text { on }\end{array}$ & Udacity（English） \\
\hline & & Design in Context: An Act of Balance & Online lecture (Chinese) \\
\hline & & Design after Modernism: Beyond the Object & $\begin{array}{l}\text { Icourse and CCTV open courses } \\
\text { (Chinese) }\end{array}$ \\
\hline
\end{tabular}

\subsection{Course Wechat social media public platform and online data analysis}

For in-depth and fully utilizing and developing online platforms, the researchers used the Chinese most prevalent mobile social media- "Wechat" to create a course public platform. In order to use its development model and function to realize course 
Paper-Creative Merging and Practical Application of "History of Modern Design" Course Online Teaching Platform Construction and Flipped Classroom Teaching Mode

public resources sharing and learning experience exchanges, the researchers not only asked students to real-time upload selected learning material information with their respective point of interest and introduce learning experiences, but also guided students to spread this course public platform to other majors' students, friends and even society. In an effort to gain attention within the maximum range, the practice could cause the inflows of outer learning resources and positive, useful experiences. After the full expansion and the formation of autonomous learning resource database, on the one hand, the researchers did the dynamic analysis of types of online learning information and related data. It manly included three aspects. The first focused on the user attribute analysis, mainly including gender analysis, age analysis, specialty distribution, the educational background analysis, university or unit type analysis, location distribution; The second aspect was the analysis of course resources construction situation and attribute analysis, mainly including resource types and quantity analysis, discussion topics and concerns information correlation analysis, learning hot degree, rallying point and keyword analysis; the third was statistics of information reading and using, there were four indexes, namely, audio and graphic video listening and browsing people number and frequency statistics; discussion, communication or comment information people number and frequency statistics; information pushing arrivals people number, sharing, resending, collection information people number and frequency statistics; clicking the related original text by the link user number and frequency statistics.

On the other hand, by gathering all kinds of autonomous learning resources and information data which was uploaded by students, the researchers plan to carry out realtime assessment and direction of the researchers plan to carry out the determination and analysis of students' learning behavior and learning performance as well as realassessment and directional guidance of students' stage learning goals, learning contents, and learning expectations of the guide. There are three steps. First of all, the researchers will combine with online data of course Wechat public platform and feedback information of students' questionnaire, and then do an inductive classification of students' learning contents, learning interests and learning expectations. This step aims to analyze, simulate and orientate students' learning behavior, learning path and learning thinking mode, and explore their deep or potential learning expectations by using data analysis method; The second step is based on announcing the analysis results of students' learning behavior and learning contents in the course WeChat public platform, the researchers can utilize the "WeActivity" function and partial loading feedback mechanism to implement targeted directed evaluation which faces to three different level groups involved course students, all the professional teachers of course offered Art School, other social people in the public platform to get evaluation feedback data. In the third step, on the basis of evaluation feedback data, through further analysis, extraction and matching, the researchers use the "WePush" function of course Wechat public platform to push the intervened guidance feedback and targeted suggestions to individual student or classified groups. This measure can help students to select more appropriate learning contents and effective learning behavior. 
Paper-Creative Merging and Practical Application of "History of Modern Design" Course Online Teaching Platform Construction and Flipped Classroom Teaching Mode

\section{$4 \quad$ Flipped Classroom Design}

\subsection{Design principle}

Step-by-step propel principle. Online leaning platform and flipped classroom teaching mode put forward new requirements, which were different from the traditional teaching mode, to universities, colleges, teachers, students and even parents of requirements, furthermore, AHPU and "History of Modern Design" course had never tired such new teaching mode and many online teaching methods. Therefore, designers, participants and related social people all needed to have a certain degree of adaptation and adjustment process. Due to this reason, this course flipped classroom design scheme abided by the principle of full communication, Combination of practice and step-by-step implementation.

Balance of release and grasp principle. Really gave the classroom back to the students, actively mobilized and exerted students' learner autonomy and initiative, fully released their potential and their own learning expertise, to enable students to always keep an active state in flipped classroom, so that students could become the protagonist and walk from back to the front. At the same time, teacher should do guidance, seize the key point and the main vein, and have a good balance of such "one release and one grasp ".

Linkage innovation principle. Introduce a variety of new teaching methods and online teaching ways to integrate and reform, to link and innovate. Simultaneously, innovation and reform experiment should be based on the university's situation and learning status, situation to achieve appropriate innovation and personalization innovation.

\subsection{Implementation Form}

To learn before to teach, completely flip. Full using of various resources to create the independent learning space, to stimulate students' motivation and interest in learning, encourage and guide students to carry out the first-in-mode and inquiry-based learning, combined with learning effect and problem feedback to implement guiding teaching and realize the full flipped classroom.

Triplicity, real-time synchronization. Using online teaching platform to create a virtual classroom and forming $\mathrm{O} 2 \mathrm{O}$ teaching mode to realize the mutual cooperation and real-time synchronization of three-in-one course system included online teaching, classroom teaching and offline autonomous learning.

Bilingual teaching, individual tutorial. According to the actual features of Sinoforeign cooperative major, teacher used bilingual teaching in face-to-face in-site classroom teaching section to systematically enhance effectiveness of students' professional English Acquisition, while timely discovered and identified their problems to regularly carry out individual counseling and tutorial for each student, and established students' individual learning records and files and provided personalized learning path to students. 
Paper-Creative Merging and Practical Application of "History of Modern Design" Course Online Teaching Platform Construction and Flipped Classroom Teaching Mode

Team implementation, cooperative learning. 5 students were a group. Implementation of collaborative learning, assigned co-completed tasks, grouping presentation and assessment could not only help students to improving communication skills, but also facilitated to enhance the sense of teamwork and group personality style learning experience.

Resources sharing, online interworking. The teacher asked students to share their own autonomous learning resources and give recommended description on online teaching platform. This approach could realize an effective expansion of learning resources, and help other students to rapidly meet the learning key points, save learning time and improve learning effect as well. The establishment of teacher-student interaction platform and setting the student inter-assessment section was an effect approach. According to assigned design tasks, small paper and other form of students' homework, teacher asked students to do the online inter-assessment. Furthermore, the teacher specially opened activate blog sub-course. Through using "Edublog" (http://edublogs.org/) education blog web station, the teacher asked students to register a blog account and create individual course blog. in addition, the teacher arranged various of learning and discussion topics to let students to deeply think and real-time publish blog to show their own feeling, emotion, learning experience, learning tips, and effectiveness. Likewise, other students could comment classmates' blog as well. (Figure 5)

\section{The road to modern design history}

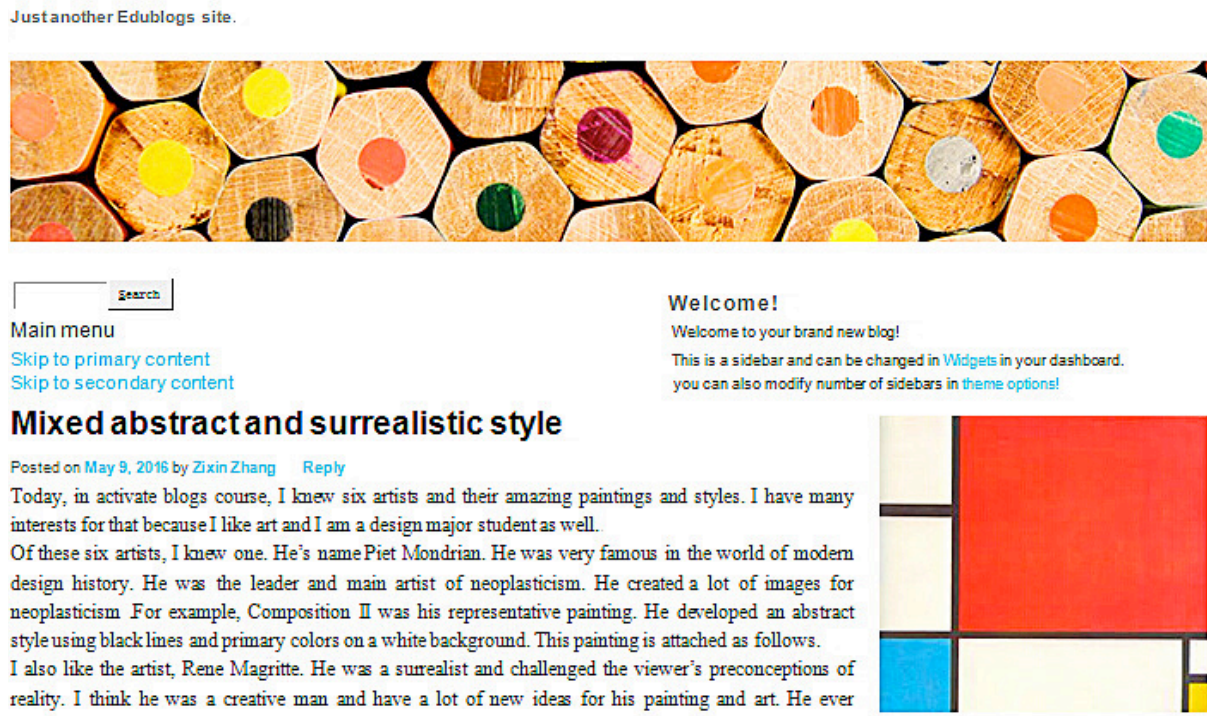

Fig. 5. Student published blog interface of History of Modern Design Activate Blog Subcourse 
Paper-Creative Merging and Practical Application of "History of Modern Design" Course Online Teaching Platform Construction and Flipped Classroom Teaching Mode

Dynamic assessment, real-time adjustment. The teacher used online questionnaires, random interviews, regularly discussion and other ways to fully know students' learning status, outcomes, effects and experience, and made adjustments on the basis of timely analysis and summary."While dynamic assessment focuses on assessing the process of skill acquisition, highlighting the integration of teaching and assessing,exploring and finding the students' learning potential and effectively interfering teaching to help consolidate teaching activities and improve learners' allaround abilities.'[9]

\subsection{Specific mode}

In order to really achieve flipped classroom, the teacher reasonable divided teaching period and students carried out online and offline hybrid autonomous learning and many other activities such as group collaborative learning, in-site classroom learning, group tasks, individual tutorial, online and offline written or design assignments, online mutual evaluation. The main stages and teaching processes were as depicted in Figures 6 and 7.

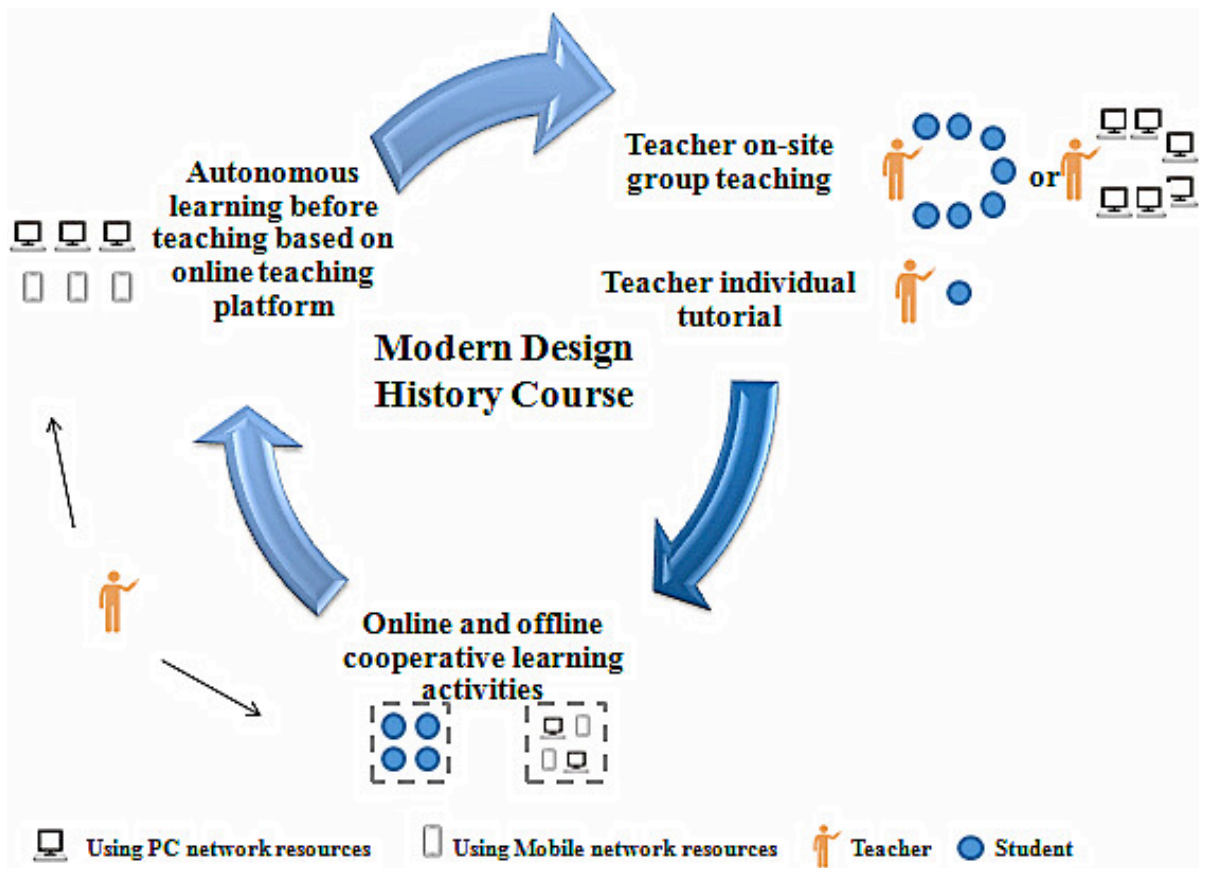

Fig. 6. Main implementation processes diagram of "History of Modern Design" flipped classroom 
Paper-Creative Merging and Practical Application of "History of Modern Design" Course Online Teaching Platform Construction and Flipped Classroom Teaching Mode

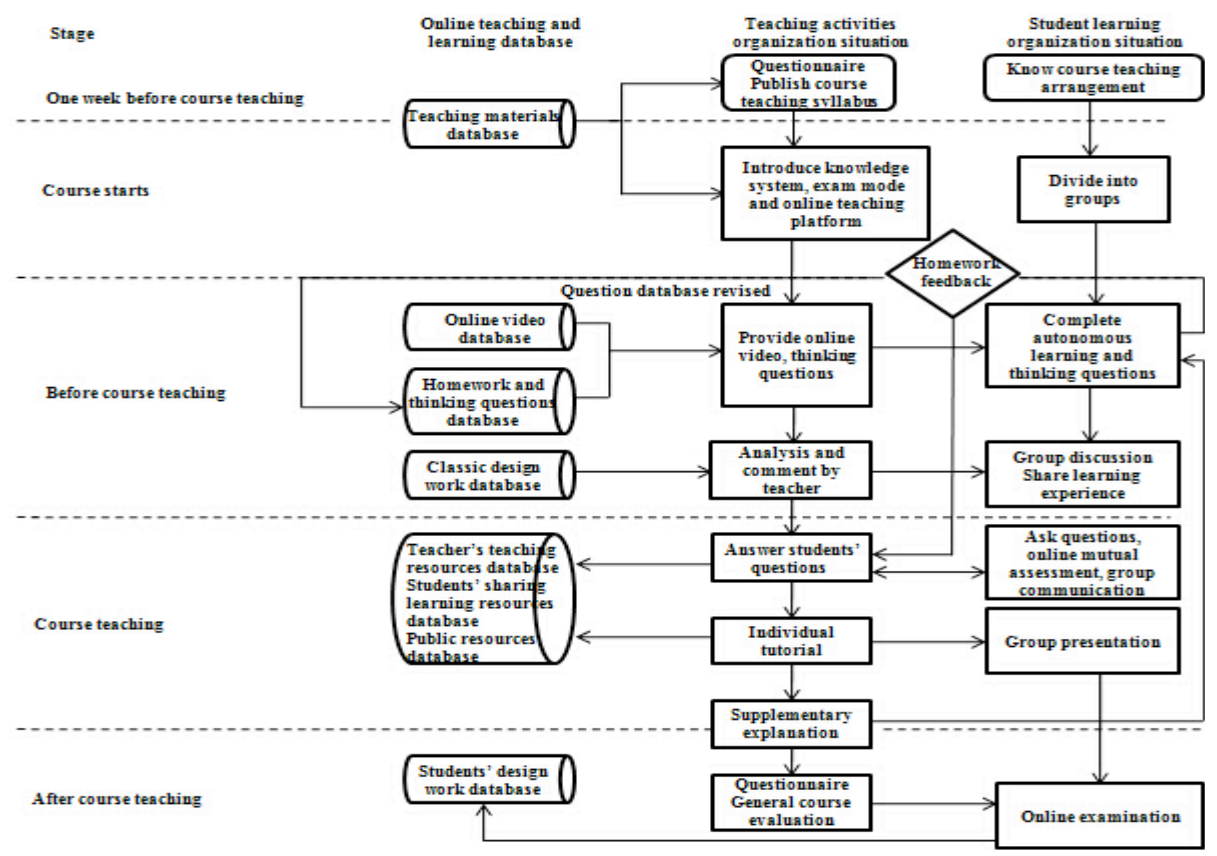

Fig. 7. Teaching mode flowchart of "History of Modern Design" flipped classroom

\section{Conclusion}

Diverse and creative construction of design history courses online teaching platform and virtual teaching environment make historical knowledge becoming vivid demonstration in modern online teaching space. Stimulation of new online interactive teaching methods, performance medium of network media, and breakthrough of the boundaries of time and space not only improve the ability of students' online learning, but also give full play to the students' individual strengths and personalities so that students can be more flexible and active to carry out various forms of personalized learning at anytime and anywhere. Analysis of the feedback of questionnaires and individual tutorial as well as online course public platform data show that the degree of student interest and learning motivation significantly improved, learning efficiency doubled and teaching effect dramatically enhanced .

Relying on flipped classroom teaching concept, the teacher combines design history teaching with design practice application. It becomes boring design theory explanation into exciting interactive teaching and flipped teaching. Through course reform, students develop their independent thinking, learning autonomy, the ability of exploration knowledge and innovative application of design history. It not only meet and exceed course teaching objectives, and because rich course teaching resources and advanced flipped classroom teaching mode on the basis of course online teaching 
Paper-Creative Merging and Practical Application of "History of Modern Design" Course Online Teaching Platform Construction and Flipped Classroom Teaching Mode

platform have a high degree of integration with international high education system, but also is completely in conformity with talent cultivation target and orientation of design Sino-foreign cooperative program.Based on "micro-video", "micro-courses" and combined with the application of modern digital online teaching platform, it changes teacher's teaching behavior so as to let teaching to adapt to learning, let teaching to assist learning, let teaching to service learning. It realizes the changing from the "traditional classroom "to" virtual classroom ", from" traditional classroom teaching mode "to" flipped classroom teaching mode ", while promotes the teacher's teaching and research level and forms a strong teaching and research atmosphere.

The successful implementation of the course teaching reform has overcome the deep-rooted problem of students' learning completely dependency of teachers' teaching which was formed during long time traditional teaching environment. It effectively promotes the formation of students' new learning habits and the cultivation of longterm learning initiative. The relationship between teachers and students has also transformed from the original dominating and being dominated into learning partnerships.

Through the construction of "History of Modern Design" course online teaching platform and the integration, innovation and practice of "to learn before to teach" pattern of flipped teaching classroom mode, it has successfully built high quality classroom and course teaching system which meet students' learning interests and learning needs. This course teaching mode can completely popularize and apply in design historical theory course teaching of design major of Chinese universities and colleges.

\section{References}

[1] Zhang Yueguo, Zhang Yujiang, Perspective on "flipped classroom" [J], information technology education in primary and secondary schools, 2012.3:9-10.

[2] Jeermy F. Stryerr, How learning in an inveretd classroom influences cooperation, innovation and task orientation[J]. Learning Environments Research, July 2012, Volume 15, Issue 2, pp 171-193.. https://doi.org/10.1007/s10984-012-9108-4

[3] Teng Mingtang, Research on the necessity of setting up the theoretical courses of art design and its curriculum setting [J]. Education and Teaching Forum, 2010.12:148-149.

[4] Zhang $\mathrm{Xu}$, The value of network teaching platform to design history courses in universities and colleges, Art Technology [J], 2014.3:412.

[5] Sun Tonghui, Throughout US high education from curriculum_- Investigation and thinking on Visual Communication Design major, Art Education [J],2011.6:22-24.

[6] Ilya V. Osipov, Anna Y. Prasikova, Alex A. Volinsky, Participant behavior and content of the online foreign languages learning and teaching platform, Computers in Human Behavior[J], 50 (2015) 476-488. https://doi.org/10.1016/j.chb.2015.04.028

[7] Sikandar Maiti Niyaz, The design and key technology of online homework and its correcting system [J], Journal of Xinjiang RTVU,2003.2:52-54.

[8] Lin Chunbo, Research on teaching Strategies of literature retrieval based on the characteristics of Art Major students[J], Educational information,2011.11:209-210.

[9] Ju Hongwei, Research on Dynamic Assessment Applied into Bilingual Teaching of Customs Declaration Practice on its Flipped Classroom [J],Journal of Hubei Correspondence University, 2016.10:138-139. 
Paper-Creative Merging and Practical Application of "History of Modern Design" Course Online Teaching Platform Construction and Flipped Classroom Teaching Mode

\section{$7 \quad$ Author}

Zhu Tiejun is with the Art school, Anhui Polytechnic University, Wuhu City, Anhui Province, 241000 P. R. China (e-mail: ztj@ahpu.edu.cn).

This work was supported by Anhui Province key education and teaching projects of universities and colleges "School running characteristics exploration and innovation of international engineer institute of Anhui Polytechnic University" (2016jyxm0091); 2017 National Social Science Fund Pre-research Project of Anhui Polytechnic University "Collaborative innovation assimilation and alienation research of intangible cultural heritage protection of the Yangtze River Delta"; Anhui provincial philosophy and social science planning project "Research on the internationalization strategy of higher education in Anhui Province "(AHSKY2016D29); "International compound students training mode of Local colleges and universities in global MOOCs era" (2014jyxm43); "Sino-foreign cooperation University programs and international application oriented innovative students training mode" (2013jyxm103); "Art major practical teaching smallsemester mode construction and implementation" (2012jyxm276). Article submitted, 07 October 2016. Published as resubmitted by the authors on 20 November 2016 . 